\title{
Increasing knowledge about nutrition and health in the elderly and cadres in Banguntapan Village, Bantul
}

\author{
Mae Sri Hartati Wahyuningsih,, ${ }^{1, *}$ Dwi Aris Agung Nugrahaningsih, ${ }^{1}$ Probosuseno ${ }^{2}$ \\ 'Department of Pharmacology and Therapy, Faculty of Medicine, Public Health, and Nursing, Universitas Gadjah Mada, \\ Yogyakarta, Indonesia \\ 2 Unit of Geriatric, Dr. Sardjito Central General Hospital, Yogyakarta, Indonesia
}

SUBMITTED: 09 April 2019 REVISED: 08 December 2019 ACCEPTED: 06 January 2020

KEYWORDS
Counseling and
discussion
Elderly
Nutrition and
health
Volunteers

ABSTRACT The increasing number of elderly is one of the social problems that require the attention of all involved parties. Health care efforts are now aimed at keeping the elderly healthy, active, independent, and productive socially and economically for themselves, their families and their community. Elderly is an age group where a person has experienced various decreases in body functions that can affect appetite, which ultimately leads to malnutrition. We designed community service-based study to increase the elderly health in the Banguntapan Village through increasing the awareness of the elderly about managing their health, the knowledge and skill to take care elderly of the families who have elderly on their care in Banguntapan Village. The method applied in this activity is counseling with pre-test and the first post-test and distribution pocket of about nutrition and elderly health. To be able to measure the retained knowledge after the activities, we also carried out the second posttest four weeks after the first meeting. The data were analyzed by descriptive analysis, and a paired t-test was performed to test the pre-test and post-test data. The total participants who participated in this activity were 144 people consisting of all cadres in Banguntapan Village, plus the elderly and families who have elderly in Karangbendo Hamlet. This research showed that there was an increase in knowledge about health and nutrition between the 1st pretestposttest; between the 1st post-test and 2nd post-test; and between the second pretest and posttest $(11.14 ; 14.86 ; 28.03) \%$. The counseling, discussion, and distribution of pocketbooks can increase the knowledge of the elderly, family and volunteer in Banguntapan and Karang Bendo Village.

(c) The Journal 2020. This article is distributed under a Creative Commons Attribution-ShareAlike 4.0 International license,

\section{Introduction}

The most recent developments in the medical and pharmaceutical world have shifted towards a healthy paradigm of preventive action before illness, namely healthy behavior through exercise awareness, healthy and nutritious food, healthy thoughts, and so forth. This shift has an impact on the emergence of the industrialization of products such as healthy food labels, food supplements, and functional food. Nutraceutical food, the provision of nutrients to regulate the body's biological functions, is also included in the industrialization of products that currently appears after the era of food supplements. Nutrition is an organic substance that plays a role in all work systems in the body so that the process takes

*Correspondence: maeshw@ugm.ac.id

Department of Pharmacology and Therapy, Faculty of Medicine, Public Health, and Nursing, Universitas Gadjah Mada, Jl. Farmako, Sekip Utara, Yogyakarta 55281, Indonesia place regularly. Nutrition also plays a role in growth and maintaining a healthy body. ${ }^{1}$

In Indonesia, there are still many cases of malnutrition in toddlers, children, adults, and even the elderly. The elderly is one of the social problems that require attention and handling from all parties of the community. Indonesian Central Bureau of Statistics (BPS) 2013 projects an estimate that the number of older people (60+) will increase to 27.1 million by $2020,33.7$ million by 2025 , and 48.2 million by $2035 .^{2}$ Long-term Development Plan in the health sector (RPJPK) 2005-2025 aims to increase awareness and the willingness to live a healthy life for everyone to realize the highest degree of public health improvement. ${ }^{3-4}$ Elderly is an age group where a person has experienced various declines in bodily functions that can affect appetite, which ultimately leads to eating disorders and malnutrition. Malnutrition is the result of insufficient and/or 
inadequate nutritional intake. ${ }^{5}$ Malnutrition in the elderly causes serious health problems, such as the impaired function of the organs, digestive system, and immunity so that it is susceptible to infection, can trigger low levels of albumin in blood serum. The long-term malnutrition also associated with increased risk of death. ${ }^{6-7}$

Based on the description above and referring to the Regional Strategy for Healthy Aging 20132018, which is a global and regional commitment, a National Strategy and National Action Plan for Elderly Health have been prepared. The immediate targets are the elderly (45-59 years old), the elderly (60-69 years old), and the high-risk elderly ( $>70$ years old or $\geq 60$ years old with health problems) while the indirect targets are families, communities, non-governmental organizations, community organizations, special groups, and the private sector, across programs, and sectors. ${ }^{8}$

Based on the population profile of Bantul District in 2018, the number of older people in Bantul reached 138,103 people consisting of 64,585 men and 73,518 women. ${ }^{9}$ Banguntapan Village is one of the villages in Bantul Regency, which consists of 11 hamlets with a population of 37,726 people, a total of 12,240 household heads, and a total of $>60$ years old people of 6,600 in 2016. Of all the elderly in the village of Banguntapan, only $25.1 \%$ were frequently examined for their health, with the most cases being hypertension, followed by the common cold. ${ }^{10}$

The low number of elderly visits to elderly healthcare center (posyandu lansia) triggers ignorance of knowledge about elderly health that has an impact on decreasing the health of the elderly in the Banguntapan Village. Therefore community service conducted on August 12, 2018, is designed to raise the awareness of the elderly for their health. The effort is through increasing the knowledge and skills of the elderly, families who have elderly, and elderly cadres in the Banguntapan Village about the importance of nutritional intake in the elderly and its dangers if the elderly are malnourished.

Based on data from the Primary Health Center (Puskesmas) Banguntapan III in 2016, the number of older people in the coverage area of the Puskesmas Banguntapan III was 6,660 , while only 1,673 were fostered or only $25.1 \%$. Also, the percentage of first level posyandu lansia in the coverage area of the Puskesmas Banguntapan III is still quite high at $25 \% .{ }^{10}$ The data shows that the activities of the posyandu lansia in the area are still not independent. This situation has the potential for the elderly not to understand the importance of health, including the importance of nutrition to support their health. Providing refresher counseling and demonstration about the benefits of nutrition for the health of the elderly is expected to motivate the elderly to attend health service places including puskesmas and posyandu lansia. In addition to increasing knowledge about nutrition for health in the Bina Keluarga Lansia (BKL) [guidance to older person families] group, the pre elderly and the elderly, as well as efforts to optimize the BKL group in the Village of Banguntapan, so that the community can apply this activity relay

A community service was carried out on August 12,2018 , by providing a pretest, counseling, posttest, and giving a nutrition pocketbook for the elderly. One month later, the second posttest was conducted. Pretest and posttest data were analyzed to find out the increase in the level of knowledge before and after counseling, and the increase in the level of knowledge again after being given a pocketbook on elderly health and nutrition. The purpose of this study is to examine the impact of counseling on increasing the knowledge of the elderly, families who have elderly, and elderly cadres. The focus of the material is the danger of malnutrition so that the health of the elderly in the Village of Banguntapan can be improved to achieve a happy old age in family and community life.

\section{Method}

The population in this study were all cadres who were invited from 11 hamlets in Banguntapan Village, plus the elderly and families who have elderly in Karangbendo Hamlet so that there were 144 people. This research has received a recommendation from the Faculty of Medicine, Public Health, and Nursing, Universitas Gadjah Mada No. ethics commission. Ref: KE / FK / 0099 / EC / 2019.

This research is a retrospective analytic study with a pre-experimental approach using secondary 
data from the results of questionnaires at the time of counseling and demonstration in the context of community service in Karangbendo Multipurpose Building, Banguntapan, Bantul, 12 August 2018 (Figure 1). A retrospective approach with a preexperimental one is a study with secondary data retrieval that has been done first. It only measured the cause variables that have occurred in the past. This pre-experimental design is comparing the knowledge level of the respondent group without the control group between pre-test (before intervention) and the first post-test (after intervention) with taking subjects without randomization. The intervention was the provision of counseling and pocketbook on the health and nutrition of the elderly, shown in Figure 2.

The difference or effect of counseling on the respondent's knowledge level was measured through the pretest and posttest immediately after the counseling. In addition, an analysis was also carried out to see the effect of giving a pocketbook to increase knowledge through a second post-test conducted one month after counseling took place. To clarify, the design of this study can be seen in Figure 3.

Data analysis was performed descriptively analytically and processed using SPSS version 2.1. Pre-test and post-test values were tested with pairedsamples t-test. Education, age, and occupational data were analyzed descriptively.

\section{Results}

Based on the data in Table 1, it was found that out of 144 participants consisting of elderly, elderly family, and elderly cadres in Karangbendo, Banguntapan, Bantul, dominated by the 45-59 years old age group $(40.3 \%)$, with the most education being senior high school $(50.7 \%)$, and most jobs are housewives as much as $27.8 \%$.
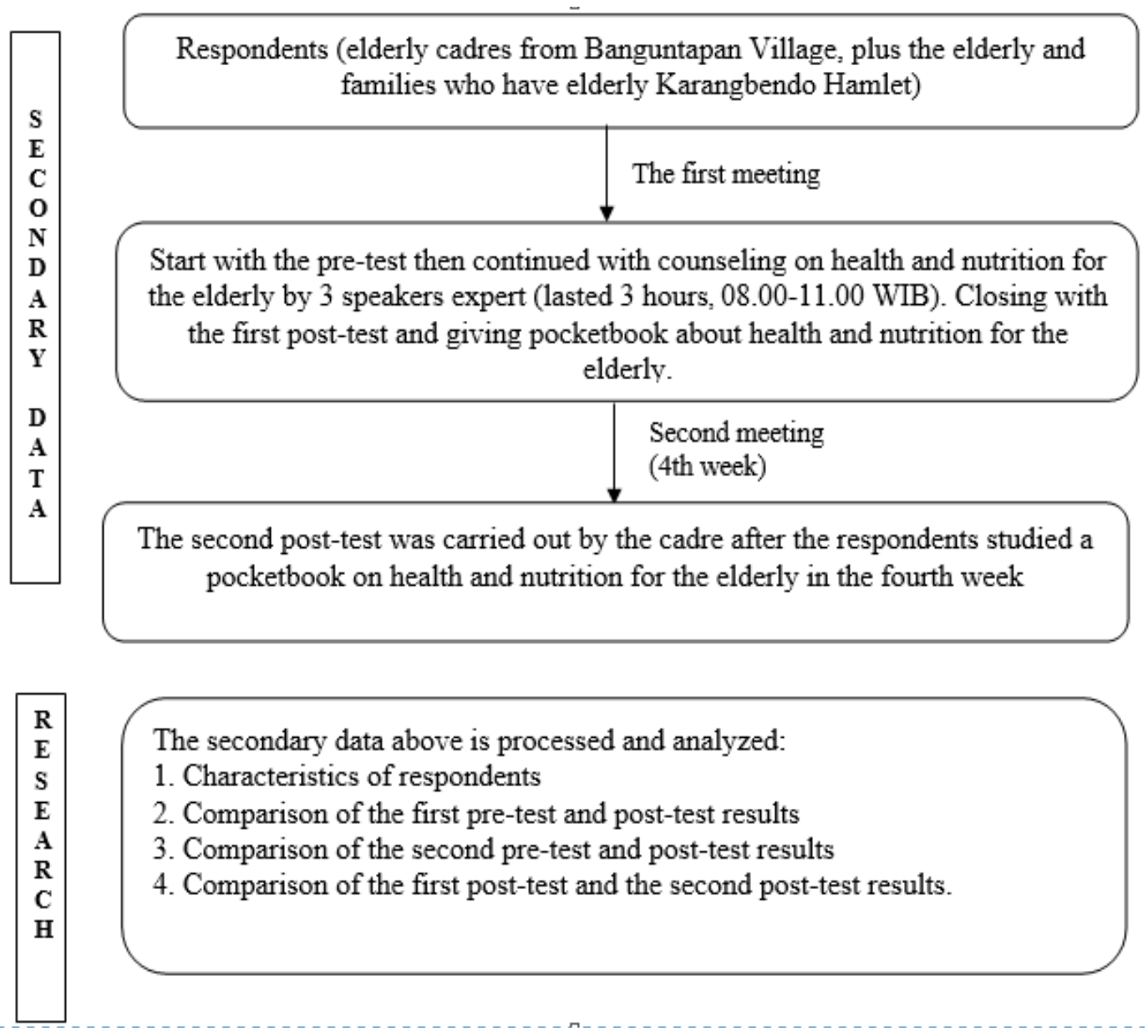

Figure 1. Research design 


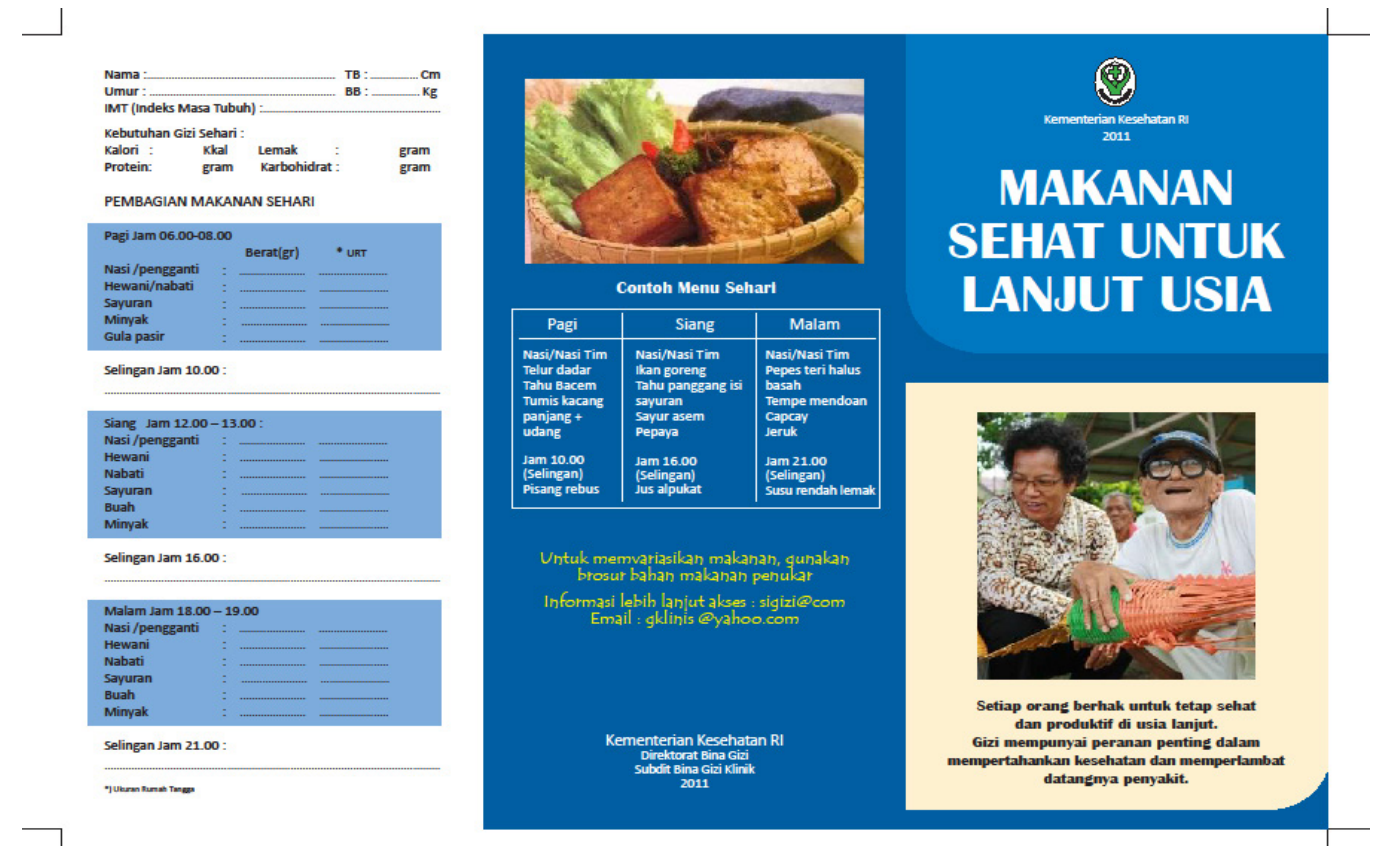

Figure 2. Health and nutrition of the elderly pocketbook
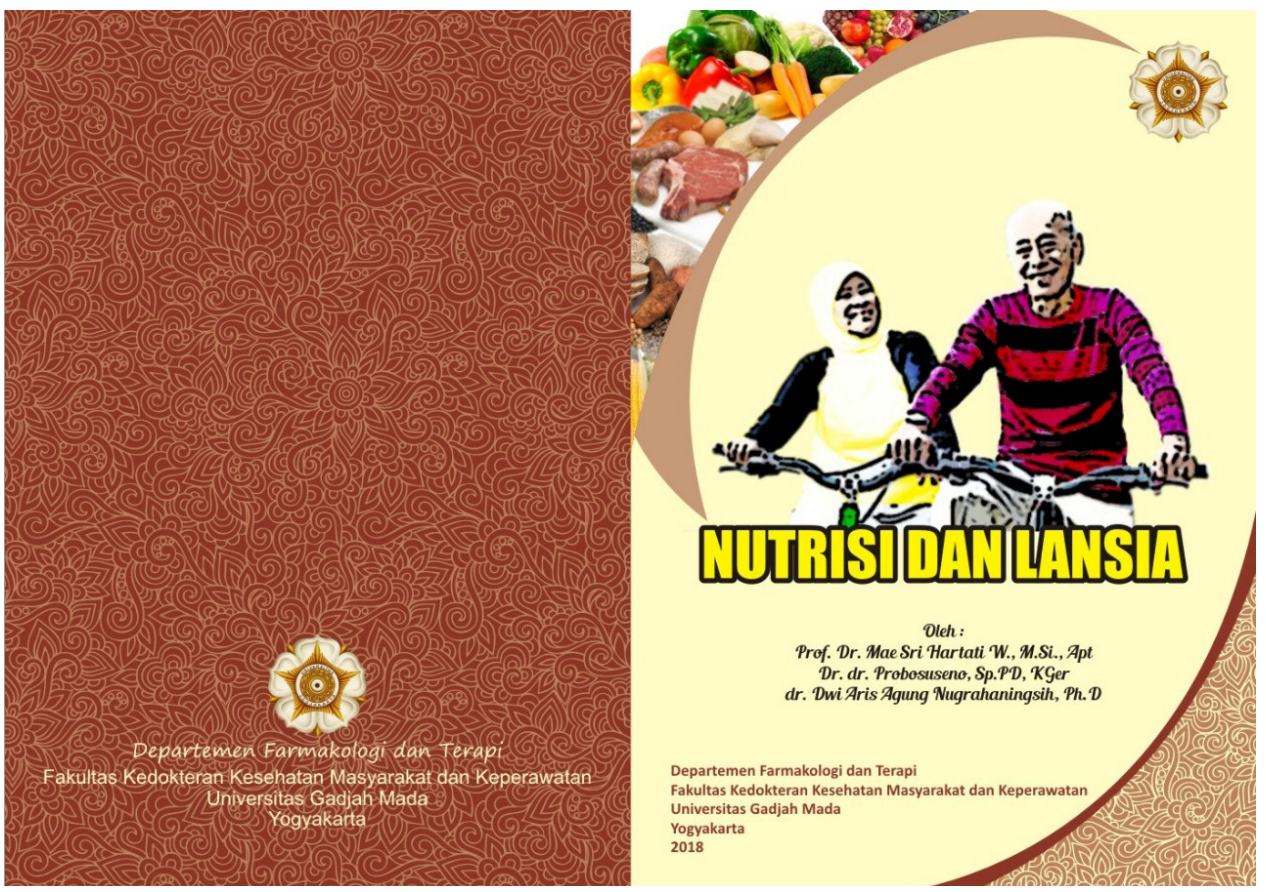

Figure 3. Pocketbook cover for elderly cadres and BKL cadres

The knowledge of participants about illness and nutrition in the elderly, the pre-test, the first posttest, and the second post-test are presented in Table 2. Furthermore, a score between the pre-test and the first post-test, the first post-test and the second post-test, and the pre-test and the second post-test were calculated.

There is an increase in the average value from the pretest to the first post-test that is equal to 8.33, and when calculated in percent, the percent increase is $11.14 \%$. The mean value also increased from the first post-test to the second post-test as well as from the pre-test to the second post-test score. The increased score in the first post-test to the second post-test was 12,36 (14.86\%). The increase from pretest to the second posttest was 20,70 (28.3\%). 


\section{Discussion}

The target population in this community service is the elderly, families who have elderly and elderly cadres throughout the village of Banguntapan, Bantul. The pre-elderly age group aged $45-59$ years dominated the arrival of this counseling (40.3\%). This is because the participants/respondents of that age were represented by elderly cadres in the village of Banguntapan, Bantul and also family members who have elderly (younger siblings, children, or grandchildren from the elderly) in Karangbendo Hamlet. In contrast, the genuinely elderly are only 40 people (34.0\%). This is because only the elderly from the Karangbendo hamlet were present in the counseling program.

The number of elderly visits participating in counseling has doubled compared to the average visit to the posyandu lansia per month, which only reaches 15-20 people. The most interesting thing is the number of elderly visits to posyandu for the elderly after counseling was held in August 2018 had increased compared to before counseling was held. The increase occurred due to the elderly health monitoring through the elderly nutrition card, which was filled in in every elderly posyandu activity. Anthropometric measurements (body weight, height, etc.), as well as questions about elderly nutrition, can stimulate the spirit of the elderly to be present at the elderly posyandu.

The results of the pretest assessment showed that before counseling, most respondents were well aware of nutrition and illness in the elderly. This can be seen from the average pre-test results, which are already quite high, namely $74.79 \pm 17.58$. When the results of the first pre-test and post-test were compared, there was an increase in scores, but only $11.14 \%$. This happened because the level of education of the majority of respondents was high school $(50.7 \%)$, and even the number of bachelor was also quite large (15.9\%). A person's education level influences the results of the respondents' questionnaire evaluation.

The second post-test was conducted to find out the respondents' understanding after being given a pocketbook about diseases related to nutrition for one month. The result turned out to be a reasonably
Table 1. Characteristics of the elderly, families who have elderly and elderly cadres in the Village of Banguntapan, Bantul ( $n=144)$

\begin{tabular}{lc}
\hline Variable & $\mathbf{n ~ ( \% )}$ \\
\hline Academic background & \\
Elementary school (SD) & $24(16.6)$ \\
Junior high school (SMP) & $21(14.6)$ \\
High school (SMA) & $73(50.7)$ \\
Associate's degree (D3) & $1(0.7)$ \\
Bachelor's degree (S1) & $23(15.9)$ \\
Master's degree (S2) & $2(1.4)$ \\
Age group & \\
<44 years & $6(4.2)$ \\
Pre elderly (45-59 years) & $58(40.3)$ \\
Elderly (60-69 years) & $49(34.0)$ \\
High-risk elderly $\geq 70 y e a r s$ & $31(21.5)$ \\
Occupation & \\
Laborers & $30(20.8)$ \\
Teachers & $2(1.4)$ \\
Housewife & $40(27.8)$ \\
Employee & $5(3.5)$ \\
Retired & $30(20.8)$ \\
Civil servants & $1(0.7)$ \\
Entrepreneurs & $2(1.4)$ \\
Other & $34(23.6)$ \\
\hline
\end{tabular}

Table 2. Pre-test, post-test 1 , and post-test $2(n=144)$

\begin{tabular}{ll}
\hline & Mean \pm SD \\
\hline Pre-test & $74.79 \pm 17.58$ \\
Post-test 1 & $83.13 \pm 14.46$ \\
Post-test 2 & $95.49 \pm 8.01$ \\
\hline
\end{tabular}

high increase. The increase may also be due to the respondent's high level of education, namely high school and even bachelor's. Knowledge is the result obtained from information, then understood, cared for, and remembered. Education can be a variety of things, including formal education and nonformal education, which can take the form of daily conversation, or come from other life experiences. ${ }^{11}$

Factors that can influence the results of nutritional knowledge are techniques or methods of delivering nutrition education materials. ${ }^{12}$ Research on increasing the knowledge of the elderly can be done using peer education methods. This peer education method is very effective for increasing knowledge and balanced nutrition behavior in the elderly compared to the counseling method. Based on these studies, the average knowledge score before peer education was $64.5 \pm 25.9$ elementary school then increased to $70.5 \pm 29.5$ elementary schools after an intervention with the peer education 
method. ${ }^{13}$

Another method that has also been proven effective in increasing respondents' knowledge is the method of active mother learning (CBIA). CBIA is a community education method that is oriented towards the active role of students in finding information, fostering attitudes, and changing behavior. This CBIA method is a method based on an independent learning process that requires several components consisting of facilitators, resource persons, and respondents. ${ }^{14}$ Research on the knowledge, attitudes, and behaviors of antibiotic use with respondents of Bina Keluarga Balita (BKB) [guidance to children families] who also use the CBIA method also showed that education on the CBIA method was proven to be able to increase the knowledge, attitudes, and behavior of antibiotic use compared to the lecture method alone. ${ }^{15}$

\section{Conclusion}

After counseling and pocketbooks on nutrition and health, there was an increase in respondents' knowledge between the pre-test and the first posttest, the first post-test and second post-test, and the second pre-test and post-test. Further research needs to be done to see the effect of increasing knowledge about the nutrition and health of the elderly on healthy living behavior and health of the elderly in the village of Banguntapan.

\section{Acknowledgement}

Our gratitude goes to the Village Head of Banguntapan, who has played an active role in raising the elderly cadre in Banguntapan. We would also like to thank the Faculty of Medicine, Public Health, and Nursing at Gadjah Mada University (FK-KMK UGM) for the grants.

\section{References}

1. Hennessy A, Browne F, Kiely M, Walton J, Flynn $A$. The role of fortified food and nutritional supplements in increasing vitamin $D$ intake in Irish Preschool children. Eur J Nutr. 2017; 56 (3): 1219-31.

2. Kementerian Kesehatan Republik Indonesia. Peraturan Menteri Kesehatan Nomor 25
Tahun 2016 Tentang Rencana Aksi Nasional Kesehatan Lanjut Usia Tahun 2016-2019. Jakarta: Departemen Kesehatan Republik Indoensia. 2016.

3. Kementrian Kesehatan Republik Indonesia. 2016. Keputusan Menkes RI No HK.02.02/ MENKES/52/2015. Rencana Strategis Kementrian Kesehatan Tahun 2015-2019.

4. Badan Penelitian dan Pengembangan Kesehatan Kementerian Kesehatan Republik Indonesia 2013. Riset Kesehatan Dasar. 2013: 70-74.

5. Maitre I, Van Wymelbeke V, Amand M, Vigneau E, Issanchou S, Sulmont-Rossé C. Food pickiness in the elderly: Relationship with dependency and malnutrition. Food quality and preference. 2014; 1(32):145-51.

6. Bruin MJ, Van Dael P, Eggersdorfer M. The role of nutrients in reducing the risk for noncommunicable disease during aging. Nutrients. 2019; 11 (1): E85.

7. Black $L$, Walton J, Flynn A, Cashman KD, Kiely $M$. Small increments in vitamin $D$ intake by Irish adults over a decade show that strategic initiatives to fortify the food supply are needed. J Nutr. 2015; 145 (5): 969-76.

8. Astuti EZL, Winarni T. Mendorong partisipasi Binal Keluarga Lansia (BKL) dalam mewujudkan tujuh dimensi lansia tangguh di Desa Sumbersari, Moyudan, Sleman. JPKM. 2018; 3(2): 130-42.

9. Dinas Kependudukan dan Pencatatan Sipil Pemerintah Kabupaten Bantul. Profil Kependudukan Kabupaten Bantul 2018; 36.

10. Puskesmas Banguntapan III. Profil Kesehatan Puskesmas Banguntapan III. Puskesmas Banguntapan. 2017; 18.

11. Petnuchova J. Non-formal and informal education: where does it go in the Slovac Republic? US-China Education Review B6. 2012; 614-625.

12. Nuryani N, Paramata Y. Intervensi Pendidik Sebaya Meningkatkan Pengetahuan, Sikap, dan Perilaku Gizi Seimbang pada Remaja di MTSN Model Limboto. Indonesian Journal of Human Nutrition. 2018; 5(2):96-112.

13. Permatasari TAE. Peningkatan Pengetahuan dan Perilaku Gizi Seimbang Menggunakan Metode 
Peer Education. Kes Mas. 2017; 11(2):114-120.

14. Suryawati S. Petunjuk Kegiatan "Meningkatkan Pengetahuan dan Ketrampilan Memilih Obat dengan Metode CBIA". Pusat Study Farmakologi Klinik dan Kebijakan Obat, Universitas Gadjah Mada, Yogyakarta. 2009.
15. Mahardika AB, Suryawati S, Rustamaji. Intervensi CBIA untuk Meningkatkan Pengetahuan, Sikap, dan Perilaku Penggunaan Antibiotik yang Rasional pada Anggota Bina Keluarga Balita. Jurnal Kedokteran Brawijaya. 2016; 29 (2): 165169. 